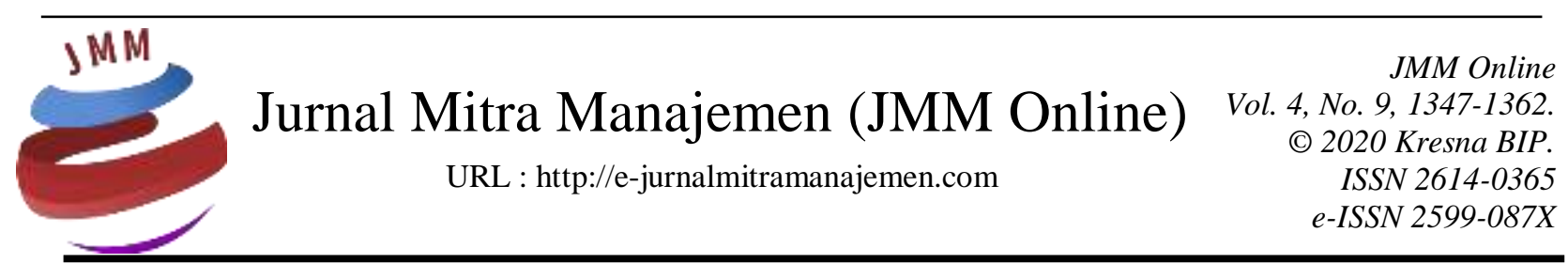

\title{
PENGARUH KEPEMIMPINAN TRANSFORMASIONAL DAN MANAJEMEN KEPALA RUANG TERHADAP KINERJA DOKUMENTASI ASUHAN KEPERAWATAN DI RUMAH SAKIT X JAKARTA
}

\author{
Eleonora Nataline 1), Anwar Kurniadi ${ }^{2)}$, Havidz Aima ${ }^{3)}$ \\ STIK Sint Carolus Jakarta ${ }^{1)}$, Universitas Pertahanan Sentul ${ }^{2)}$, \\ Universitas Mercu Buana Jakarta ${ }^{3)}$
}

\section{INFORMASI ARTIKEL}

Dikirim : 07 September 2020

Revisi pertama : 08 September 2020

Diterima : 14 September 2020

Tersedia online : 01 Oktober 2020

Kata Kunci: Kepemimpinan Transformasional, Manajemen Kepala Ruang, Kinerja Dokumentasi Asuhan Keperawatan

Email : eleonoranataline@gmail.com

\section{ABSTRAK}

Kinerja dokumentasi asuhan keperawatan adalah fungsi penting dari praktik keperawatan profesional. Terlepas dari berbagai upaya peningkatan secara global, dokumentasi yang tidak memadai terus terjadi dan dilaporkan. Sehingga penting menyelidiki penyebabnya terutama yang berkaitan dengan kepemimpinan dan manajemen. Tujuan penelitian ini adalah mengetahui dan menjelaskan pengaruh kepemimpinan transformasional, manajemen kepala ruang dan demografi (usia, jenis kelamin, lama kerja, pendidikan) terhadap kinerja dokumentasi asuhan keperawatan. Penelitian ini menggunakan pendekatan kuantitatif dengan metode penelitian cross-sectional terhadap 51 orang perawat di rumah sakit X Jakarta. Pengumpulan data dilakukan melalui kuesioner kepemimpinan transformasioal, kuesioner manajemen kepala ruang dan lembar penilaian dokumentasi asuhan keperawatan di ruang rawat inap rumah sakit X Jakarta. Analisis data dengan menggunakan analisis univariat, bivariat dan multivariat dengan teknik regresi linear berganda menggunakan SPSS 25. Hasil penelitian menunjukan kepemimpinan tranformasioanl berpengaruh signifkan terhadap kinerja dokumentasi asuhan keperawatan dengan hasil Pvalue < 0,005. Manajemen kepala ruang berpengaruh signifikan terhadap kinerja dokumentasi asuhan keperawatan dengan Pvalue <0,005. Faktor demogafi (usia, lama kerja, pendidikan, jenis kelamin) tidak berpengaruh terhadap kinerja dokumentasi asuhan keperawatan.

Kepemimpinan transformasional, manajemen kepala ruang, faktor demogafi (usia, lama kerja, pendidikan, jenis kelamin) secara bersama sama berpengaruh signifikan terhadap kinerja dokumentasi asuhan keperawatan. 


\section{PENDAHULUAN \\ Latar Belakang}

Kinerja dokumentasi asuhan keperawatan adalah fungsi penting dari praktik keperawatan profesional. Terlepas dari berbagai upaya peningkatan secara global, dokumentasi yang tidak memadai terus terjadi dan dilaporkan. Sehingga penting menyelidiki penyebabnya terutama yang berkaitan dengan kepemimpinan dan manajemen. Kinerja adalah suatu evaluasi terhadap kualitas kerja perawat dibandingkan dengan standar yang ditetapkan dalam kurun waktu tertentu (Kurniadi, 2013). Penilaian kinerja keperawatan secara akuntabilitas dalam melakukan asuhan keperawatan meliputi empat komponen yaitu: pengkajian, perencanaan, implementasi dan evaluasi. Empat komponen tersebut adalah penilaian terhadap kinerja dokumentasi asuhan keperawatan sesuai dengan standar asuhan keperawatan (Kurniadi, 2013). Dalam Systematic review tentang kinerja oleh Nuritasari et .al, (2019) ditemukan bahwa supervisi klinis yang merupakan bagian dari manajemen kepala ruang memiliki potensi untuk meningkatkan kinerja staf, yang pada akhirnya akan memengaruhi keberhasilan pencapaian rumah sakit.

Penelitian Suratno (2018), kepemimpinan transformasional secara signifikan terkait dengan QNWL (Quality Of Nursing Work Life) dengan ( $\mathrm{p}=0,000, \mathrm{r}=0,28$ ). Kepemimpinan transformasional memiliki pengaruh langsung pada QNWL. Abdelrhaman \& Abd-allah (2018), kesimpulan penelitian menunjukkan bahwa ada peningkatan yang sangat signifikan secara statistik dalam skor pengetahuan dan keterampilan kepala perawat tentang kepemimpinan transformasional. Dan ada peningkatan kinerja staff perawat secara signifikan tiga bulan setelah program pelatihan. Abdullah (2017), hasil penelitian menunjukkan bahwa gaya kepemimpinan transformasional berpengaruh signifikan terhadap kinerja perawat. Wartana (2019), gaya kepemimpinan transformasional kepala keperawatan berpengaruh signifikan terhadap kinerja perawat. Gani (2020), kepemimpinan transformasional berpengaruh secara positif dan signifikan terhadap kinerja perawat dan kepuasan kerja. Penelitian yang berbeda dari Ibrahim et.all (2019, menemukan tidak ada hubungan yang signifikan secara statistik antara gaya kepemimpinan terhadap kinerja perawat. Penelitian Lai et. al (2020) menemukan bahwa kepemimpinan transformasional berhubungan kuat (positif) dengan keterlibatan kerja (work engagement), kinerja dan perilaku membantu (helping behavior). Oleh karena itu peneliti menganjurkan kepada pemimpin transformasional agar menunjukkan berbagai perilaku untuk memelihara dan meningkatkan status psikologis yang berkontribusi pada keterlibatan kerja bawahanya. Pemimpin transformasional dapat meningkatkan kinerja bawahanya dengan membantu perilaku kerja, mendorong keterlibatan kerja anggota dan memungkinkan mereka untuk melampaui harapan.

Manajemen kepala ruang adalah serangkaian proses yang dimulai dari perencanaan, pengorganisasian, staffing, pengarahan, dan pengendalian yang satu sama lain saling terkait. Peran manajer keperawatan tidak terlepas dari proses manajemen yang dilakukan, termasuk memberikan perhatian kepada sumber daya material maupun sumber daya manusia keperawatan. Peran manajer yang diterapkan secara nyata mampu membawa transformasi bagi staf keperawatan lainnya untuk 
menerapkan standar mutu keperawatan. Standar ditetapkan untuk mengukur kinerja asuhan dan pelayanan keperawatan yang bersifat obyektif, dapat diukur, dan dapat dicapai (Huber, 2018).

Penelitian tentang manajemen kepala ruang terhadap kinerja oleh Rezky et.all (2017), mengatakan ada hubungan peran kepala ruangan dengan kinerja perawat di ruang rawat inap. Rezkiki \& Ilfa (2018) hasil penelitian terdapat pengaruh yang signifikan pelaksanaan supervisi terhadap kelengkapan dokumentasi asuhan keperawatan. Hasil audit kelengkapan dokumentasi asuhan keperawatan Rumah Sakit X Jakarta adalah $38,1 \%$ dari target $85 \%$ pencapaian yang telah ditetapkan oleh rumah sakit. Dari 20 dokumen pasien yang dinilai dari pengkajian sampai dengan evaluasi nilai tertinggi adalah pengajian (22\%), evaluasi (10\%), diagnosa keperawatan (3\%), implementasi $(1,1 \%)$ dan intervensi (2\%). Menurut beberapa perawat yang diwawancarai oleh peneliti hal yang menyebabkan rendahnya hasil dokumentasi tersebut adalah kurangnya supervisi atau pengarahan, jumlah tenaga yang belum optimal, fasilitas kurang lengkap, tidak cukup waktu untuk menulis dan kurangnya pengetahuan tentang asuhan keperawatan.

\section{Rumusan Masalah}

Berdasarkan latar belakang diatas, maka rumusan masalah dalam penelitian ini adalah sebagai berikut.

1. Apakah kepemimpinan transformasional berpengaruh signifikan terhadap kinerja dokumentasi asuhan keperawatan di Rumah Sakit X Jakarta ?

2. Apakah manajemen kepala ruang berpengaruh signifikan terhadap kinerja dokumentasi asuhan keperawatan di Rumah Sakit X Jakarta?

3. Apakah faktor demografi (usia, pendidikan, lama kerja, jenis kelamin) berpengaruh signifikan terhadap kinerja dokumentasi asuhan keperawatan di Rumah Sakit X Jakarta?

4. Apakah kepemimpinan transformasional, manajemen kepala ruang dan faktor demografi secara bersama sama berpengaruh terhadap kinerja dokumentasi asuhan keperawatan di Rumah Sakit X Jakarta?

\section{Tujuan Penelitian}

Berdasarkan rumusan masalah diatas, maka tujuan dalam penelitian ini adalah sebagai berikut.

1. Mengetahui dan menjelaskan pengaruh kepemimpinan transformasional terhadap kinerja dokumentasi asuhan keperawatan Rumah Sakit X Jakarta.

2. Mengetahui dan menjelaskan pengaruh manajemen kepala ruang terhadap kinerja dokumentasi asuhan keperawatan Rumah Sakit X Jakarta.

3. Mengetahui dan menjelaskan pengaruh faktor demografi (usia, pendidikan, lama kerja, jenis kelamin) terhadap kinerja dokumentasi asuhan keperawatan Rumah Sakit X Jakarta.

4. Mengetahui dan menjelasakan pengaruh kepemimpinan transformasional, manajemen kepala ruang dan faktor demografi (usia, pendidikan, lama kerja dan jenis kelamin) secara bersama sama terhadap kinerja dokumentasi asuhan keperawatan Rumah Sakit X Jakarta. 


\section{KAJIAN PUSTAKA \\ Kepemimpinan Transformasional}

Berikut ini adalah dimensi dan indikator kepemimpinan yang dijadikan sebagai acuan dalam penelitian ini: Bass \& Avolio dalam Suwatno \& Priansa (2011) mengemukakan terdapat empat dimensi kepemimpinan transformasional yang terdiri dari: a.) Idealized influence. Perilaku seorang pemimpin transformasional yang memiliki keyakinan diri yang kuat, selalu hadir di saat-saat sulit, memegang teguh nilai-nilai moral, menumbuhkan kebanggaan pada pengikutnya, yang bervisi jelas, dan langkah-langkahnya selalu mempunyai tujuan yang pasti, dan agar bawahan mau mengikutinya secara suka rela, ia menempatkan dirinya sebagai tauladan bagi para pengikutnya tersebut. b) Inspirational motivation. Merupakan upaya pemimpin transformasional dalam memberikan inspirasi para pengikutnya agar mencapai kemungkinan yang tidak terbayangkan untuk mencapai standar yang tinggi. c) Intellectual simulation. Pemimpin harus mampu merangsang karyawannya untuk memunculkan ide-ide dan gagasan-gagasan baru, pemimpin juga harus membiarkan karyawannya menjadi problem solver dan memberikan inovasi-inovasi baru dibawah bimbingannya. c) Individualized consideration. Pemimpin harus memberikan perhatian, mendengarkan keluhan, dan mengerti kebutuhan karyawannya.

\section{Manajemen Keperawatan (Kepala Ruang)}

Pelayanan keperawatan sangat dipengaruhi oleh bagaimana manajer keperawatan melaksanakan peran dan fungsinya Pengelolaan pelayanan keperawatan menggunakan pendekatan manajemen kepala ruang yaitu melalui fungsi perencanaan, pengorganisasian, pengarahan dan pengawasan dan pengendalian. (Huber, 2018). Marquis \& Huston (2017) membagi proses manajemen menjadi lima tahap yaitu planning, organizing, staffing, directing, controling yang merupakan satu siklus yang saling berkaitan satu sama lain.

1. Perencanaan. Perencanaan (planning), merupakan fungsi dasar dari manajemen dan semua fungsi dalam manajemen tergantung dari fungsi perencanaan. Maksudnya fungsi-fungsi yang lain dari manajemen tidak akan berjalan secara efektif tanpa adanya perencanaan yang baik. Oleh karena itu perencanaan harus mengandung unsur-unsur yang dapat menjawab What, Why, Where, When, Who dan How (Huber, 2018).

2. Pengorganisasian. Pengorganisasian adalah keseluruhan pengelompokan orangorang, alat-alat, tugas tugas, kewenangan dan tanggung jawab sehingga tercipta suatu organisasi yang dapat digerakkan sebagai suatu kesatuan dalam rangka mencapai tujuan yang telah ditetapkan. (Huber, 2018).

3. Pengarahan. Fungsi pengarahan selalu berkaitan erat dengan perencanaan kegiatan keperawatan di ruang rawat inap dalam rangka menugaskan perawat untuk melaksanakan mencapai tujuan yang telah ditentukan. (Huber, 2018).

4. Pengawasan. Proses terakhir dari manajemen adalah pengawasan atau pengontrolan. Pengontrolan adalah pemeriksaan apakah segala sesuatu yang terjadi sesuai dengan rencana yang telah disepakati, instruksi yang dikeluarkan, serta prinsip-prinsip yang ditentukan. (Huber, 2018). 


\section{Kinerja Keperawatan}

Menurut Gillies kinerja keperawatan adalah suatu proses menilai tentang asuhan keperawatan pada pasien untuk mengevaluasi kelayakan dan keefektifan tindakan. Perawat yang melakukan tindakan bertanggung jawab, dimana hal ini akan meningkatkan akuntabilitas perawat itu sendiri. Penilaian kinerja perawat adalah sebuah proses dimana pencapaian kinerja individu atau kelompok diukur dan di evaluasi serta dibandingkan dengan standar yang telah ditentukan. Tolok ukur penilaian yang beroerintasi kepada perawat adalah berdasarkan kepada standar proses keperawatan. Standar keperawatan meliputi lima kompenen yaitu: 1) Pengkajian. Pengkajian adalah tahap awal untuk mendapatkan informasi kesehatan pasien dan menentukan masalah kesehatanya. 2) Diagnosa keperawatan. Diagnosa keperawatan adalah pernyataan jelas, singkat dan pasti tentang masalah pasien serta pengembangan yang dapat dipecahkan atau diubah melalui tindakan keperawatan. 3) Perencanaan. Perencanaan adalah penyusunan rencana tindakan keperawatan yang akan dilaksanakan untuk menanggulangi masalah pasien sesuai dengan diagnosa keperawatan yang telah ditentukan oleh terpenuhinya kebutuhan pasien. 4) Implementasi. Implementasi adalah pelaksanaan rencana tindakan yang telah ditentukan dengan maksud agar kebutuhan pasien terpenuhi. 5) Evaluasi. Evaluasi adalah proses penilaian pencapaian tujuan serta pengkajian ulang rencana keperawatan (Kurniadi, 2013)

\section{Kerangka Pemikiran}

Dalam menyusun kerangka konsep (pemikiran) penelitian ini, peneliti mereduksi beberapa teori yang telah dipaparkan dalam tinjuan pustaka antara lain: Diagram skematis teori perilaku dan kinerja Gibson, James L., Ivancevich, John M., Dan Donelly JR, James H dalam Nursalam 2015 121, Robbins \& Judge, 2015, Robert House dalam Kurniadi (2013) Kerangka konsep digunakan untuk menjawab pertanyaan atau masalah penelitian.

\section{Gambar 1. Kerangka Pemikiran}

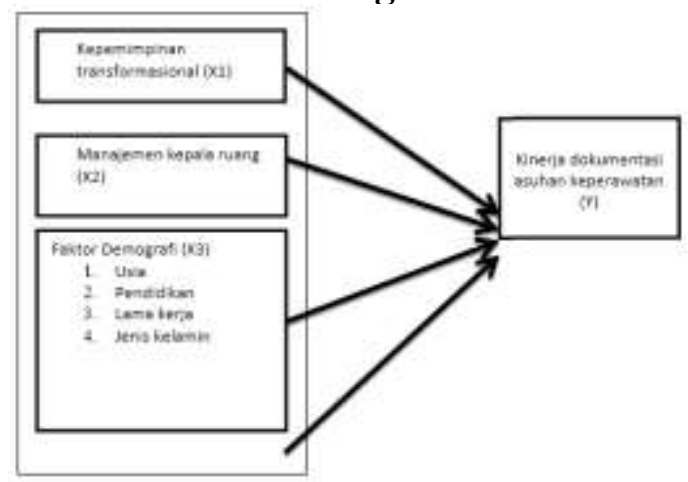

\section{METODE PENELITIAN \\ Jenis Penelitian}

Penelitian ini menggunakan pendekatan metode kuantitatif dengan desain penelitian cross sectional. Desain penelitian cross sectional adalah suatu penelitian 
dimana faktor risiko atau penyebab dan efeknya diambil pada saat bersamaan (Supardi \& Rustika, 2013). Sedangkan menurut Sugiyono metode penelitian cross sectional adalah penelitian yang digunakan untuk mencari pengaruh atau hubungan antara variabel dengan waktu bersamaan (Sugiyono, 2018). Penelitian ini dilakukan untuk melihat besar pengaruh variabel terikat (kepemimpinan transformasional, manajemen kepala ruang dan faktor demografi) terhadap varibel bebas (kinerja dokumentasi asuhan keperawatan). Dalam penelitian ini juga akan menentukan variabel independen terhadap variabel dependen secara simultan yang bertujuan untuk melihat faktor yang memiliki pengaruh yang paling signifikan terhadap kinerja dokumentasi asuhan keperawatan. Penelitian ini dilakukan pada tanggal 27-29 Juli 2020 di ruang rawat inap lantai 7, 5 dan 4 Rumah Sakit X Jakarta.

\section{Teknik Pengumpulan Data}

Penelitian ini menggunakan rumus slovin dan teknik consecutive sampling dalam menentukan jumlah responden. Dari hasil perhitungan menggunakan rumus Slovin, sampel yang dapat diambil sebesar 86 kemudian didapatkan hasil responden sebanyak 51 responden yang merupakan perawat penanggung jawab dan perawat pelaksana yang melakukan dokumentasi asuhan keperawatan di ruang rawat inap Rumah Sakit X Jakarta.

\section{Teknik Analisis Data}

1. Analisis Univariat. Analisis univariat adalah analisis satu variabel dapat dalam bentuk distribusi frekuensi, ukuran penyebaran dan nilai rata-rata (Supardi \& Rustika, 2013). Analisis univariat dalam penelitian ini adalah umur, pendidikan, lama kerja, kepemimpinan transformasional, manajemen kepala ruang dan kinerja dokumentasi asuhan keperawatan.

2. Analisis Bivariat. Analis bivariat yang digunakan dalam penelitian ini adalah uji regresi linear sederhana. Uji regresi linear sederhana pada variabel independen dengan skala inverval atau ratio. Regresi linear sederhana digunakan untuk mengeksplorasi sifat hubungan antara dua variabel acak dan memiliki skala kontinu (data metrik).

3. Uji Asumsi Klasik. Asumsi-asumsi diperlukan dalam regresi linear berganda. Tujuannya adalah untuk memperoleh nilai penaksir atau nilai koefisien $\alpha$ dan $\beta$ yang tidak biasa sehingga menjadi nilai yang terbaik. Uji asumsi klasik antara lain: Uji normalitas, Kolmogorov-Smirnov, uji multikolinearitas, uji heteroskedastisitas

4. Analisis Multivariat. Analisis multivariat yang digunakan dalam penelitian ini adalah analisis regersi linear berganda dan analisis matriks korelasi antar dimensi.

a. Regresi Linear Berganda. Regresi linear berganda adalah model regresi linear dengan melibatkan lebih dari satu variabel bebas atau predictor. Analisis regresi linear berganda digunakan untuk mengukur pengaruh antara lebih dari satu variabel prediktor (variabel bebas) terhadap variabel terikat (Susilo Aima \& Suprapti, 2014).

b. Analisis Matriks Korelasi Antar Dimensi. Analisis matriks kolerasi antar dimensi digunakan untuk mengetahui korelasi dimensi variabel independen terhadap variabel dimensi variabel dependen. 


\section{HASIL PENELITIAN DAN PEMBAHASAN \\ Hasil Penelitian}

Hasil penelitian ini terdiri dari uji univariat, uji asumsi klasik dan uji multivariat dengan regresi linear berganda dan uji matriks korelasi antar dimensi yang akan dijelaskan dibawah ini:

\section{Analisis Univariat}

a. Responden Berdasarkan Usia

Dari hasil analisis univariat diatas didapatkan presentase usia terbanyak adalah 25-30 tahun sebanyak 42 responden $(82,4 \%)$.

b. Responden Berdasarkan Pendidikan

Dari hasil analisis univariat diatas didapatkan presentase pendidikan terbanyak adalah DIII Keperawatan sebanyak 46 responden $(90,2 \%)$

c. Responden Berdasarkan Lama Kerja

Dari hasil analisis univariat diatas didapatkan presentase lama kerja terbanyak adalah 1-5 tahun (junior) sebanyak 41 responden $(80,4 \%)$

d. Responden Berdasarkan Jenis Kelamin

Dari hasil analisis univariat diatas didapatkan presentase jenis kelamin terbanyak adalah perempuan sebanyak 45 responden $(88,2 \%)$.

e. Kepemimpinan Transformasional

Dari hasil analisis univariat diatas didapatkan presentase kepemimpinan transformasional terbanyak adalah kategori baik sebanyak 41 responden $(80,4 \%)$.

f. Manajemen Kepala Ruang

Dari hasil analisis univariat diatas didapatkan presentase manajemen kepala ruang terbanyak adalah baik sebanyak 41 responden $(80,4 \%)$

g. Kinerja Dokumentasi Asuhan Keperawatan

Dari hasil analisis univariat diatas didapatkan presentase kinerja dokumentasi asuhan keperawatan terbanyak adalah kategori baik sebanyak 45 responden (70,6\%). Hasil tersebut sudah cukup baik namun belum mencapai standar yang telah ditetapkan oleh rumah sakit yaitu sebesar $85 \%$.

2. Analisis Bivariat

a. Uji hubungan usia terhadap hasil kinerja dokumentasi asuhan keperawatan

Dari hasil analisa hubungan usia terhadap hasil kinerja dokumentasi asuhan keperawatan didapatkan Pvalue $0.776>0,05$ yang artinya tidak ada hubungan usia terhadap hasil kinerja dokumentasi asuhan keperawatan asuhan keperawatan.

b. Uji hubungan pendidikan terhadap hasil kinerja dokumentasi asuhan keperawatan

Dari hasil analisa hubungan pendidikan terhadap hasil kinerja dokumentasi asuhan keperawatan didapatkan Pvalue $0.584>0,05$ yang artinya tidak ada hubungan pendidikan terhadap hasil kinerja dokumentasi asuhan keperawatan.

c. Uji hubungan lama kerja terhadap hasil kinerja dokumentasi asuhan keperawatan

Dari hasil analisa hubungan lama kerja terhadap hasil kinerja dokumentasi asuhan keperawatan asuhan keperawatan didapatkan Pvalue $0.737>0,05$ yang 
artinya tidak ada hubungan lama kerja terhadap hasil kinerja dokumentasi asuhan keperawatan.

d. Uji hubungan jenis kelamin terhadap hasil kinerja dokumentasi asuhan keperawatan asuhan keperawatan

Dari hasil analisa hubungan jenis kelamin terhadap hasil kinerja dokumentasi asuhan keperawatan didapatkan Pvalue $0.986>0,05$ yang artinya tidak ada hubungan jenis kelamin terhadap hasil kinerja dokumentasi asuhan keperawatan.

3. Analisis Multivariat

a. Uji Asumsi Klasik

1) Uji Normalitas. Sebelum melakukan analisis lebih lanjut untuk mengetahui apakah data penelitian berdistribusi normal maka terlebih dahulu perlu dilakukan uji normalitas, dilakukan dengan menggunakan scatterplot. Dari hasil pengujian diperoleh hasil Grafik histogram menunjukkan bentuk yang meruncing tinggi, yang dapat disebabkan karena perbedaan frekuensi pada skor-skor yang mendekati rata-rata sangat kecil, jenis grafik seperti ini disebut leptokurtic. Walaupun demikian grafik histogram masih terbentuk seperti lonceng, yang mengindikasikan pola distribusi normal dari data.Berdasarkan hasil pengolahan data, hasil uji normalitas dengan menggunakan Two Sample Kolmogorov-Smirnov adalah variabel Y $(\mathrm{p}=0.078), \mathrm{x} 1(\mathrm{p}=0.080) \times 2(\mathrm{p}=0.092)$ maka dapat disimpulkan bahwa data berdistribusi normal karna $\mathrm{p}$ dari setiap variabel lebih besar dari 0,025

2) Multikolinieritas

Berdasarkan hasil pengujian, didapatkan nilai tolerance yang lebih besar dari 0,10 dan nilai VIF yang lebih kecil dari 10 menunjukkan bahwa tidak terjadi multikolinearitas atau hubungan linear di antara variabel independen. Dapat disimpulkan bahwa uji multikolonieritas terpenuhi.

b. Analisis Regresi Linear Berganda

\begin{tabular}{|c|c|c|c|c|c|}
\hline \multirow[t]{2}{*}{ Model } & \multicolumn{2}{|c|}{$\begin{array}{l}\text { Unstandardized } \\
\text { Coefficients }\end{array}$} & \multirow{2}{*}{$\begin{array}{l}\text { Standardized } \\
\text { Coefficients } \\
\text { Beta }\end{array}$} & \multirow[t]{2}{*}{$\mathbf{T}$} & \multirow[t]{2}{*}{ Sig. } \\
\hline & $\mathrm{B}$ & $\begin{array}{l}\text { Std. } \\
\text { Error }\end{array}$ & & & \\
\hline (Constant) & $-0,553$ & 0,262 & & $-2,110$ & 0,040 \\
\hline $\begin{array}{l}\text { KEPEMIMPINAN } \\
\text { TRANSFORMASIONAL }\end{array}$ & 0,751 & 0,102 & 0,655 & 7,376 & 0,000 \\
\hline Manajemen kepala ruang & 0,501 & 0,102 & 0,437 & 4,921 & 0,000 \\
\hline
\end{tabular}

Sumber, Hasil Penelitian, diolah (2020)

Persamaan regresi yang terbentuk di atas dapat dijelaskan sebagai berikut:

a) Konstan $\beta 0=-0.553$. Artinya nilai variabel hasil kinerja dokumentasi asuhan keperawatan (Y) adalah sebesar -0.553 apabila variabel kepemimpinan transformasional $\left(\mathrm{X}_{1}\right)$ dan manajemen kepala ruang $\left(\mathrm{X}_{2}\right)$ bernilai nol. Secara konseptual, meskipun semua nilai variabel independen bernilai nol, hasil kinerja dokumentasi asuhan keperawatan bernilai negatif karena masih ada variabel lain atau faktor lain yang menentukan hasil kinerja dokumentasi asuhan keperawatan dan tidak digunakan sebagai variabel penelitian 
b) Koefisien Regresi Kepemimpina transformasional $\left(b_{1}\right)=0,751$. Artinya peningkatan kepemimpinan transformasional $\left(\mathrm{X}_{1}\right)$ sebesar satu satuan akan meningkatkan hasil kinerja dokumentasi asuhan keperawatan keperawatan sebesar 0,751 atau $75.1 \%$ dengan asumsi variabel lain tetap.

c) Koefisien manajemen kepala ruang $\left(b_{2}\right)=0,501$. Artinya peningkatan manajemen kepala ruang $\left(\mathrm{X}_{2}\right)$ sebesar satu satuan akan meningkatkan hasil audit dokumerntasi keperawatan sebesar 0,501 atau $50.1 \%$, dengan asumsi variabel lain tetap. Hasil ini menunjukkan bahwa kepemimpinan transformasional dan manajemen kepala ruang yang semakin baik, akan berimplikasi pada hasil kinerja dokumentasi asuhan keperawatan, dan sebaliknya semakin buruk kepemimpinan transformasional dan manajemen kepala ruang semakin buruk pula hasil kinerja dokumentasi asuhan keperawatan.

c. Pengujian Variabel Bebas secara Simultan (Uji F)

ANOVAa

\begin{tabular}{lllllll}
\hline Model & & \multicolumn{1}{c}{$\begin{array}{c}\text { Sum of } \\
\text { Squares }\end{array}$} & Df & $\begin{array}{c}\text { Mean } \\
\text { Squares }\end{array}$ & F & Sig. \\
\hline 1 & Regression & 6,586 & 2 & 3,293 & 39,491 & \multirow{2}{*}{, $000 \mathrm{~b}$} \\
& Residual & 4,002 & 48 &, 083 & & \\
& Total & 10,558 & 50 & & & \\
\hline
\end{tabular}

Sumber : Hasil Penelitian, diolah (2020)

a. Dependent Variable: Hasil kinerja dokumentasi asuhan keperawatan

b. Predictors: (Constant), manajemen kepala ruang, kepemimpinan transformasional, demografi

Berdasarkan tabel di atas diperoleh nilai Fhitung sebesar 39,491. Nilai

Ftabel diperoleh dengan cara menggunakan rumus : $(\mathrm{Df}(\mathrm{n} 1)=\mathrm{k}$, Df $(\mathrm{n} 2)=\mathrm{n}-$ $\mathrm{k}-1$ ) dimana $\mathrm{N}$ adalah jumlah data dan $\mathrm{K}$ adalah jumlah variabel independen sehingga menjadi (Df $(\mathrm{n} 1)=2$ dan $\mathrm{Df}(\mathrm{n} 2)=51$ ), jadi didapatkan nilai Ftabel sebesar 2,74. Dalam hal ini Fhitung $(39,491)>$ Ftabel $(2,74)$ artinya Ho ditolak dan Ha diterima. Nilai signifikan diperoleh 0,000 lebih kecil dari 0,05. Sehingga hasil uji $\mathrm{F}$ pada penelitian ini dapat disimpulkan bahwa kepemimpinan transformasional, manajemen kepala ruang dan faktor demografi berpengaruh positif secara bersama-sama (simultan) terhadap kinerja dokumentasi asuhan keperawatan.

d. Pengujian Variabel Bebas secara Parsial (Uji t)

\begin{tabular}{lll}
\hline Model & T & Sig. \\
\hline (Constant) & $-2,110$ & 0,040 \\
KEPEMIMPINAN TRANSFORMASIONAL & 7,376 & 0,000 \\
Manajemen kepala ruang & 4,921 & 0,000 \\
\hline
\end{tabular}

Sumber : Hasil Penelitian, diolah (2020)

Berdasarkan tabel diatas dapat diambil kesimpulan:

1. Skor thitung untuk variabel kepemimpinan transformasional 7,376. Nilai ttabel dengan menggunakan rumus $\mathrm{df}=\mathrm{n}-1$ (satu ekor/0,05) $=50$ jadi didapatkan nilai ttabel sebesar 1,664. Maka diperoleh thitung $>$ ttabel. Nilai signifikan pada variabel kepemimpinan adalah 0,000 lebih kecil dari 0,05, disimpulkan bahwa Ho ditolak dan Ha diterima, artinya kepemimpinan transformasional secara parsial berpengaruh signifikan terhadap hasil kinerja dokumentasi asuhan keperawatan. 
2. Skor thitung untuk variabel manajemen kepala ruang 4,921 Nilai ttabel dengan menggunakan rumus $\mathrm{df}=\mathrm{n}-1($ satu ekor/0,05) $=50$ jadi didapatkan nilai ttabel sebesar 1,664. Maka diperoleh thitung > ttabel. Nilai signifikan pada variabel manajemen kepala ruang adalah 0,000 lebih kecil dari 0,05, sehingga dapat disimpulkan bahwa Ho ditolak dan Ha diterima, artinya manajemen kepala ruang secara parsial berpengaruh signifikan terhadap hasil kinerja dokumentasi asuhan keperawatan.

e. Uji Koefisien Determinasi (R Square)

\begin{tabular}{|c|c|c|c|c|}
\hline Model & $\mathbf{R}$ & R Square & $\begin{array}{l}\text { Adjusted R } \\
\text { Square }\end{array}$ & $\begin{array}{l}\text { Std. Error of the } \\
\text { Estimate }\end{array}$ \\
\hline 1 &, $789 a$ & 0,622 & 0,606 & 0,289 \\
\hline \multicolumn{5}{|c|}{$\begin{array}{l}\text { a. Predictors: (Constant), Manajemen kepala ruang, KEPEMIMPINAN } \\
\text { TRANSFORMASIONAL }\end{array}$} \\
\hline
\end{tabular}

\section{Sumber : Hasil Penelitian, diolah (2020)}

Berdasarkan hasil pengujian pada tabel di atas, diperoleh nilai koefisien determinasi $\left(\mathrm{R}^{2}\right)$ sebesar 0,622. Ini mengindikasikan bahwa pengaruh yang diberikan oleh variabel independen (kepemimpinan transformasional dan manajemen keperawatan) terhadap variabel dependen (kinerja dokumentasi asuhan keperawatan) adalah sebesar 62\%, sementara sisanya yaitu $38 \%$ dipengaruhi oleh faktor lain.

f. Uji Matriks Korelasi Antar Dimensi

\begin{tabular}{|l|l|l|l|l|l|l|}
\hline \multirow{2}{*}{ Variabel } & \multirow{2}{*}{ Dimensi } & \multicolumn{5}{c|}{ Hasil Kinerja dokumentasi asuhan keperawatan (Y) } \\
\cline { 3 - 7 } & & $\begin{array}{c}\text { Y1 } \\
\text { pengkajian }\end{array}$ & $\begin{array}{c}\text { Y2 } \\
\text { Diagnosa }\end{array}$ & $\begin{array}{c}\text { Y3 } \\
\text { Perencanaan }\end{array}$ & $\begin{array}{c}\text { Y4 } \\
\text { implementasi }\end{array}$ & $\begin{array}{c}\text { Y5 } \\
\text { evaluasi }\end{array}$ \\
\hline $\begin{array}{l}\text { Kepemimpinan } \\
\text { Transformasional } \\
\text { (X1) }\end{array}$ & $\begin{array}{l}\text { Ideallized } \\
\text { influence }\end{array}$ & 0,156 & $-0,179$ & $-0,056$ & $-0,068$ & 0,072 \\
\cline { 2 - 7 } & $\begin{array}{l}\text { Inspirational } \\
\text { motivation }\end{array}$ & 0,072 & $-0,027$ & $-0,091$ & 0,102 & 0,234 \\
\cline { 2 - 7 } & $\begin{array}{l}\text { Intellectual } \\
\text { simulation }\end{array}$ & 0,009 & $-0,209$ & $-0,083$ & $-0,029$ & $-0,079$ \\
\cline { 2 - 7 } & $\begin{array}{l}\text { Individualized } \\
\text { consideration }\end{array}$ & $-0,015$ & $-0,120$ & $-0,091$ & $-0,006$ & 0,234 \\
\hline $\begin{array}{l}\text { Manajemen } \\
\text { kepala ruang } \\
\text { (X2) }\end{array}$ & Perencanaan & 0,169 & 0,096 & 0,100 & 0,070 & 0,074 \\
\cline { 2 - 7 } & pengorganisasian & 0,241 & 0,137 & 0,143 & 0,100 & 0,106 \\
\cline { 2 - 7 } & Pengarahan & $-0,169$ &,$- 299^{*}$ &,$- 286^{*}$ & 0,100 & $-0,14$ \\
\cline { 2 - 7 } & Pengawasan & 0,036 & 0,137 & 0,143 & 0,100 & 0,106 \\
\hline
\end{tabular}

Sumber : Hasil Penelitian, diolah (2020)

Berdasarkan Tabel diatas maka hasil koefisien korelasi variabel dapat diartikan sebagai berikut: Mengacu pada matriks korelasi antar dimensi, korelasi yang terkuat adalah dimensi Inspirational motivation terhadap dimensi evaluasi, dimensi Individualized consideration terhadap dimensi evaluasi dan dimensi pengorganisasian terhadap pengkajian

\section{Pembahasan \\ Distribusi frekuensi}

Hasil analisis univariat memperlihatkan data demografi responden dengan presentase usia terbanyak 25-30 tahun. Pendidikan terbanyak DIII, lama kerja 
terbanyak junior dan mayoritas responden adalah perempuan. Hasil analisis kepemimpinan transformasional dan manajemen keperawatan terbanyak adalah kriteria baik. Hasil audit dokumentasi terbanyak adalah kriteria baik. Hal ini menunjukkan bahwa semakin baik kepemimpinan transformasional dan manajemen keperawatan maka semakin baik pula kinerja dokumentasi asuhan keperawatan. Kepemimpinan transformasional dan manajemen keperawatan memiliki kontribusi yang sama atau signifikan terhadap kinerja dokumentasi asuhan keperawatan hal ini senada dengan penelitian Patelarou \& Vlasiadis (2014) yang mengatakan kepemimpinan dan manajeman memiliki pengaruh terhadap kinerja perawat.

\section{Pengaruh Kepemimpinan Transformasioanl Terhadap Kinerja Dokumentasi Asuhan Keperawatan}

Pada uji regresi ditemukan bahwa kepemimpinan transformasional berpengaruh signifikan terhadap kinerja dokumentasi asuhan keperawatan sebesar 62\%, sementara sisanya yaitu 38\% dipengaruhi oleh faktor lain. Hasil ini di dukung oleh penelitian Abd-elrhaman \& Abd-allah (2018), Abdullah (2017). Berbeda dengan penelitian Rayatin (2018) yang menemukan bahwa gaya kepemimpinan paling dominan berhubungan dengan kinerja adalah servant leader. Faktor lain sebanyak $38 \%$ di Rumah Sakit X menurut wawancara dan pengamatan oleh peneliti adalah fasilitas yang belum memadai, pengetahuan asuhan keperawatan standar terbaru masih kurang dan jumlah tenaga yang belum optimal. Hal ini didukung oleh penelitian Saputra (2018) yang menemukan bahwa hal yang berpengaruh terhadap dokumentasi bukan hanya kepemimpinan namun ada faktor lain yaitu pengetahuan, sikap, supervisi dan kelengkapan fasilitas. Faktor lain yang mungkin memengaruhi kinerja selain kepemimpinan adalah kepuasan kerja. Sesuai dengan penelitian. Hasil penelitian Arisa \& Syah (2018) menemukan bahwa gaya kepemimpinan transformasional kepala ruang yang baik akan meningkatkan kepuasan kerja dan kinerja perawat. Pemimpin yang memiliki perhatian atau dukungan terhadap bawahan memiliki tingkat kepuasan kerja yang lebih tinggi dibandingkan mereka yang tidak peduli dengan bawahannya. Kepuasan kerja yang tinggi akan meningkatkan kinerja perawat perawat dibandingkan dengan mereka yang merasa tidak puas.

\section{Pengaruh Manajemen Keperawatan Terhadap Kinerja Dokumentasi Asuhan Keperawatan}

Pada uji regresi ditemukan bahwa manajemen keperawatan berpengaruh signifikan terhadap kinerja dokumentasi asuhan keperawatan sebesar $62 \%$, sementara sisanya yaitu $38 \%$ dipengaruhi oleh faktor lain. Hal ini didukung oleh penelitian Kalikwani (2014), Rezkiki \& Ilfa (2018) dan Rezky et.all (2017). Berbeda dengan Kamil, Rachmah, \& Wardani (2018) faktor yang berpengaruh terhadap dokumentasi adalah: 1) Supervisi terhadap dokumentasi tidak adekuat. 2) Kompetensi pendokumentasian kurang. 3) Kepercayaan diri. Penelitian lain yang berbeda oleh Yani, Wahyuni, Priscilla, (2019) menemukan ada hubungan antara fungsi pengarahan dengan kualitas dokumentasi asuhan keperawatan (pvalue=0,042) tapi tidak ada hubungan fungsi perencanaan, pengorganisasian, dan pengawasan terhadap dokumentasi. Faktor lain yang penting untuk ditelusuri adalah adanya kemungkinan 
faktor kelelahan karena pengaturan tenaga yang belum adequat yang menyebabkan kelelahan. Faktor ini di dukung oleh penelitian Sagherian (2019) yang mengatakan, perawat dengan kelelahan akut dan kronis menyebabkan kinerja fisik yang lebih buruk. Kelelahan juga menyebabkan kurang waspada dan kurang bisa berkonsentrasi saat memberi perawatan pasien. Kesimpulannya, kelelahan memiliki pengaruh terhadap keamanan kerja dan kinerja perawat sehingga harus dipantau oleh manajemen keperawatan.

\section{Pengaruh Faktor Demografi (Usia, Lama Kerja, Pendidikan, Jenis Kelamin) Terhadap Kinerja Dokumentasi Asuhan Keperawatan}

a) Usia. Dari hasil analisa hubungan usia terhadap hasil kinerja dokumentasi asuhan keperawatan didapatkan Pvalue $0.776>0,05$ yang artinya tidak ada hubungan usia terhadap hasil kinerja dokumentasi asuhan keperawatan asuhan keperawatan. Hal ini sejalan dengan pendapat Robbins \& Judge (2015) yang mengatakan tidak ada hubungan usia dengan kinerja. Namun berbeda penelitian Handayani, Fannya dan Nazofah (2018) dengan hasil uji statistik didapatkan $p$ value $=0,001(p<0,05)$ artinya Ho ditolak dan Ha diterima dapat disimpulkan ada hubungan karakteristik umur dengan tingkat kinerja perawat. Usia mayoritas responden adalah 25-35 tahun semuanya masuk ketegori generasi millenal. Menurut asumsi peneliti generasi millineal adalah generasi yang inovatif kreatif dalam bekerja namun meraka perlu di dukung oleh tegnologi yang memudahkan meraka untuk berinovasi dalam bekerja. Pengamatan lapangan oleh peneliti bahwa belum ada saranan seperti e - medical record atau formulir yang singkat dan aplikatif. b) Pendidikan. Dari hasil analisa hubungan pendidikan terhadap hasil kinerja dokumentasi asuhan keperawatan didapatkan Pvalue $0.584>0,05$ yang artinya tidak ada hubungan pendidikan terhadap hasil kinerja dokumentasi asuhan keperawatan. Hasil ini sama dengan penelitian Thulth \& Sayej (2015) mengatakan bahwa tidak ada pengaruh yang signifikan antara pendidikan dan kinerja. Namun Robbins \& Judge (2015) mengatakan ada hubungan yg positif antara intelektual dengan organisasi. Mayoritas responden adalah DIII (diploma 3) dimana dari segi keilmuan tidak terlalu menguasai manajemen asuhan keperawatan. Asumsi peneliti adalah ada faktor lain di RS X yang perlu diperhatikan seperti pengaturan ketenagaan (staffing) dan kelengkapan fasilitas. c) Lama Kerja. Dari hasil analisa hubungan lama kerja terhadap hasil kinerja dokumentasi asuhan keperawatan asuhan keperawatan didapatkan Pvalue $0.737>0,05$ yang artinya tidak ada hubungan lama kerja terhadap hasil kinerja dokumentasi asuhan keperawatan. Sejalan dengan penelitian Karyo Ahsan dan Setyoadi (2016) yang mengatakan tidaka ada hubungan lama kerja dengan kinerja. Mayoritas responden adalah perawat junior yang mungkin masih kurang pengetahuan dan pengalaman dalam menyelesaikan pekerjaan sehingga penting untuk memberikan pelatihan yang terkait dengan dokumentasi asuhan keperawatan. Selain itu perlu dilakukan program preseptorship untuk perawat baru dan selanjutnya program mentoring untuk perawat 1-2 tahun. Dengan demikian perawat bisa dibimbing bekerja sesuai dengan target yang ingin dicapai oleh rumah sakit d) Jenis Kelamin. Dari hasil analisa hubungan jenis kelamin terhadap hasil kinerja dokumentasi asuhan keperawatan didapatkan Pvalue $0.986>0,05$ yang artinya tidak ada hubungan jenis kelamin terhadap hasil kinerja dokumentasi asuhan keperawatan. 
Hasil ini sesuai dengan penelitian Imlabla, Rahayu dan Soepangat (2018) di salah satu rumah sakit Jakarta. Namun Robbins \& Judge (2015) mengatakan sebuah studi metanalis terbaru atas kinerja menemukan bahwa wanita meraih skor yang sedikit lebih tinggi dibandingkan dengan pria dalam ukuran- ukuran kinerja. Mayoritas responden adalah wanita sehingga seharusnya sesuai dengan pendapat Robbins maka kinerja dokumentasi asuhan keperawatan rumah RS X seharusnya baik.

\section{Korelasi Matriks Antar Dimensi (Faktor Pengungkit)}

Hasil uji matriks korelasi antar dimensi pada kepemimpinan transformasional terhadap kinerja dokumentasi asuhan keperawatan memiliki korelasi. Hasil yang tertinggi dari dimensi kepemimpinan transformasional adalah dimensi Inspirational motivation, dan Individualized consideration terhadap dimensi evaluasi. Hal ini sama dengan temuan Wartana (2019) dimana Individualized consideration yang paling berpengaruh terhadap kinerja namun kepemimpinan transformasional secara keseluruhan berpengaruh lemah terhadap kinerja. Pada variabel manajemen keperawatan yang tertinggi adalah dimensi pengorganisasian terhadap pengkajian. Hal ini di dukung oleh penelitian Rezky \& Ilfa (2018). Inspirational motivation menggambarkan pemimpin yang mengkomunikasikan harapan tinggi kepada pengikut, menginspirasi mereka lewat motivasi untuk menjadi setia, dan menjadi bagian dari visi bersama dalam organisasi. Individualized consideration faktor ini mewakili pemimpin yang memberikan iklim yang mendukung, dimana mereka mendengarkan dengan seksama kebutuhan masing-masing pengikut. Pemimpin bertindak sebagai pelatih dan penasihat, sambil mencoba untuk membantu pengikut benar-benar mewujudkan apa yang diinginkan. Pengorganisasian dapat diaplikasikan melalui pembagian kerja, kesatuan komando, rentang kendali, dan koordinasi. (Huber, 2018). Oleh karena itu dimensi Inspirational motivation, Individualized consideration, dan pengorganisasian dinilai mempunyai daya ungkit strategis untuk meningkatkan kinerja. Manajemen rumah sakit harus memberikan perhatian yang sungguh-sungguh terhadap keempat dimensi tersebut.

\section{Uji Hipotesis}

Hasil pengujian Hipotesis (Ha1) Kepemimpinan transformasional (X1) berpengaruh signifikan terhadap kinerja dokumentasi asuhan keperawatan (Y). Hipotesis (Ha2) Manajemen keperawatan (X2) berpengaruh signifikan terhadap kinerja dokumentasi asuhan keperawatan (Y). Hipotesis (Ha3) faktor demografi (usia, pendidikan, lama kerja, jenis kelamin) tidak berpengaruh terhadap kinerja dokumentasi asuhan keperawatan. Hipotesis (Ha4) Kepemimpinan transformasional (X1), manajemen keperawatan (X2) dan faktor demografi (X3) (usia, lama kerja, pendidikan, jenis kelamin) secara bersama sama berpengaruh signifikan terhadap kinerja dokumentasi asuhan keperawatan (Y)

\section{Keterbatasan Penelitian}

Keterbatasan yang ditemukan dalam penelitian ini adalah terkait dengan pandemi covid 19 yang menyebabkan peneliti tidak bisa melakukan penelitian 
terhadap semua perawat rawat inap. Karena ruang khusus suspect covid dan ICU adalah area rawan yang tidak dijinkan untuk melakukan kegiatan penelitian.

\section{Implikasi Hasil Penelitian}

Hasil penelitian ini memberikan implikasi bagi pelayanan keperawatan, pendidikan keperawatan, dan penelitian keperawatan: 1) Bagi Pelayanan Keperawatan. Hasil penelitian ini memberikan kontribusi bagi pengembangan skill kepemimpinan dan manajemen perawat khususnya perawat manajer. Penelitian ini memberikan data yang menggabarkan kinerja dokumentasi asuhan keperawatan yang dapat dijadikan acuan oleh keperawatan untuk perubahan kebijakan, SPO (standar prosedur operasional) dan program.2) Bagi Pendidikan Keperawatan. Hasil penelitian ini memberikan tambahan informasi terkait kepemimpinan transformasioal dan manajemen kepala ruang yang dapat digunakan oleh mahasiswa keperawatan selama proses pembelajaran. 3) Bagi Penelitian Keperawatan.Hasil penelitian ini memberikan gambaran pengaruh kepemimpinan transformasional dan manajemen kepala ruang dan mampu meningkatkan pengembangan penelitian selanjutnya terutama terhadap faktorfaktor kinerja dokumentasi yang belum diteliti dalam peneliti

\section{KESIMPULAN DAN SARAN \\ Kesimpulan}

1. Kepemimpinan transformasional berpengaruh signifikan terhadap kinerja dokumentasi asuhan keperawatan Rumah Sakit X Jakarta.

2. Manajemen kepala ruang berpengaruh signifikan terhadap kinerja dokumentasi asuhan keperawatan Rumah Sakit X Jakarta.

3. Faktor demografi (usia, lama kerja, pendidikan, jenis kelamin) tidak berpengaruh signifikan terhadap kinerja dokumentasi asuhan keperawatan.

4. Kepemimpinan transformasional, manajemen kepala ruang dan faktor demografi (usia, pendidikan, lama kerja, jenis kelamin) secara bersama sama berpengaruh signifikan terhadap kinerja dokumentasi asuhan keperawatan

\section{Saran}

Berdasarkan hasil analisis pembahasan dan beberapa kesimpulan di atas, maka saran-saran yang dapat diberikan untuk melengkapi hasil penelitian ini, yaitu sebagai berikut: 1) Divisi Keperawatan. Melakukan revisi standar asuhan keperawatan sesuai dengan standart Persatuan Perawat Nasional Indonesia (PPNI). Membuat program pelatihan terkait dengan dokumentasi asuhan keperawatan yang sesuai standar PPNI. Menyediakan sarana yang berkaitan dengan proses pendokumentasian. Membuat program pelatihan kepemimpinan transformasional dan manajemen kepala ruang menjadi training yang wajib diikuti oleh seluruh perawat. 2) Divisi Sumber Daya Manusia. Bekerja sama dengan divisi keperawatan dalam membuat program training standar asuhan keperawatan sesuai dengan standar terbaru PPNI dan pelatihan kepemimpinan transformasional dan manajemen kepala ruang. 3) Manajemen Rumah Sakit Mendukung Divisi Keperawatan dalam penyediaan sarana dan prasarana terkait dokumentasi. Mendukung Divisi Keperawatan untuk meningkatkan pengetahuan dan skill melalui pelatihan sumber daya manusia. 4) Pendidikan. Penelitian selanjutnya, 
diharapkan dapat melakukan penelitian dengan variabel-variabel lain yang dapat meningkatkan kinerja dokumentasi asuhan keperawatan.

\section{DAFTAR PUSTAKA}

Abd-elrhaman, E. S. A., \& Abd-allah, N. A. 2018. Transformational Leadership Educational Program for Head Nurses and its Effect on Nurses 'Job Performance, 7(4), 127-136. https://doi.org/10.11648/j.ajns.20180704.13

Abdullah., I. 2017. Pengaruh Gaya Kepemimpinan terhadap Kinerja Perawat di Rumah Sakit Ibnu Sina Makassar. 2017. UMI Med J. (2019) ;4(1):102-110. doi:10.33096/umj.v4i1.53

Al-Ibrahim et al. 2016. Relationship between Head Nurses' leadership styles and Staff Nurses' job performance. J Nurs Sci. 2016; 5(1):66-74. doi:10.9790/195905146674

Al Shiah Public Heal Sci J. 2017; 9 (1): 94-102. journal.uinalauddin.ac.id/index.php/Al- Sihah/article/view/3199

Arisa F,. Syah TYR. 2018. How Transformational Leadership Style of Head Nurse the Influence on Performance of Nurses by Mediated Job Satisfaction : A Case Study in Hospital Industry Indonesia. IOSR J Bus Manag (IOSR-JBM. 2018; 20 (8):62-69. doi:10.9790/487X-2008056269

Gibson, J.L., Ivancevich, J.M., Konopaske, R. 2011. Organizations: Behavior, structure, Processess. (14 th. Ed). McGraw-Hill Education

Gani., A. A., 2020. Pengaruh Gaya Kepemimpinan Transformasional dan Disiplin Kerja Terhadap Kinerja Pegawai. Bisma J Manaj. ;5(1):9-16.

Huber. D. 2018. Leadership and Nursing Care Management. 6 th Edition. Printed In China

Kalikwani, F. (n.d.). 2014. Improving the quality of nursing documentation: An action researchproject,1-11.https://doi.org/10.4102/curationis.v37i1.1251

"Nurse manager" and "nurse leader"- Synonyms or complementary terms? (n.d.), 42-47.

Kamil, H., Rachmah, R., \& Wardani, E. 2018. International Journal of Africa Nursing Sciences What is the problem with nursing documentation? Perspective of Indonesian nurses. International Journal of Africa Nursing Sciences, 9 (December 2017), 111-114. https://doi.org/10.1016/j.ijans.2018.09.002

Karyo., Ahsan., Setyoadi., 2016. Analisis Faktor-Faktor Yang Mempengaruhi Kinerja Perawat Gawat Darurat. J Kesehat Mesencephalon.;2 (4):231-237. doi:10.36053/mesencephalon.v2i4.11

Kurniadi, A. 2013. Manajemen kepala ruang dan Prospektifnya: Teori, Konsep dan Aplikasi. Jakarta: Fakultas Kedokteran Universitas Indonesia

Lai, F. Y., Tang, H. C., Lu, S. C., Lee, Y. C., \& Lin, C. C. 2020. Transformational Leadership and Job Performance: The Mediating Role of Work Engagement.

SAGE Open, 10(1). https://doi.org/10.1177/2158244019899085

Marquis \& Husten. 2015. Leadership Roles and Management Functions in Nursing: Theory and Application. 8 th Edition. US: Lippincott

Nuritasari, R. T., Rofiqi, E., Fibriola, T. N., \& Ardiansyah, R. T. 2019. Systematic Review The Effect of Clinical Supervision on Nurse Performance, 14(3), 3-6. 
Nursalam. 2015. Manajemen kepala ruang Aplikasi Dalam Praktik Keperawatan Profesional. (edisi 5). Jakarta: Salemba Medika

Patelarou \& Vlasiadis. 2014. "Nurse manager' and 'nurse leader'- Synonyms or complementary terms?," n.d.)

Rezky.,Raodhah. S., Nildawati., 2017. Hubungan Peran Kepala Ruangan dengan Kinerja Perawat di Ruang Rawat Inap RSUD Syekh Yusuf Kabupaten Gowa.

Rezkiki. F \& Ilfa. A,. 2018. Pengaruh Supervisi Terhadap Kelengkapan Dokumentasi Asuhan Keperawatan di Ruangan Non Bedah Fitrianola. (2018);1(1):1 8.

Robbins, P.S., Judge, T.A. 2015. Perilaku Organisasi Ed 16. Jakarta : Salemba Empat

Sagherian K, Clinton ME, Abu-Saad Huijer H, Geiger-Brown J. Fatigue, Work Schedules, and Perceived Performance in Bedside Care Nurses. Work Heal Saf. 2017;65(7):304-312. doi:10.1177/2165079916665398

Saputra, M. A. 2018. The Influence of Nursing Care Documenting Behavior on the Completeness of Nursing Care Documentation at Hospital X, 7(August), 170 177. https://doi.org/10.18196/jmmr.72

Sugiyono. 2018. Metode Penelitian Kuantitatif, Kualitatif dan R\&D: Bandung. Alfabeta Bandung.

Suratno, K. 2018. The Relationship between Transformational Leadership and Quality of Nursing Work Life in Hospital, 11(3), 1416-1422

Susilo, H. W., Aima, H.M., Suprapti, F. 2014. Biostatistika Lanjut dan Aplikasi Riset: Kajian Medikal Bedah Pada Ilmu Keperawatan Dengan Analisis Uji Beda, Regresi Linear Berganda dan Regresi Logistik Aplikasi Program SPSS. Jakarta: Trans Info Media

Suwatno \& Priansa D. 2011. Manajemen SDM dalam Organisasi Publik dan Bisnis. Bandung: Alfabeta.

Soepangat., S .Imlabla. F.V., Rahayu.S. 2018. Pengaruh Karakteristik Individu, Faktor Organisasi dan Motivasi Terhadap Kinerja Perawat di Rumah Sakit Tk. II Moh. Ridwan Meuraksa, Jakarta (1):34-48.

Wartana., I. K., 2019. Pengaruh Gaya Kepemimpinan Transformasional Kepala Bidang Keperawatan terhadap Kinerja Perawat Pada Rumah Sakit Umum Daerah Anutaloko Kabupaten Parigi Moutong 